\title{
SELEKTIVITAS GILLNET YANG MENANGKAP SUMBERDAYA IKAN LAYUR (Trichiurus lepturus) DI KABUPATEN PANGANDARAN
}

Gillnet Selectivity that Catched Trichiurus lepturus in Pangandaran District

Oleh:

Lantun Paradhita Dewanti ${ }^{1}$, Yafi Ibnu Sienna ${ }^{1}$, Alexander Khan ${ }^{1}$, Izza Mahdiana Apriliani $^{1}$, Heti Herawati ${ }^{1}$

${ }^{1}$ Fakultas Perikanan dan Ilmu Kelautan, Universitas Padjadjaran, Indonesia Korespondensi: lantun.paradhita@unpad.ac.id

\begin{abstract}
ABSTRAK
Ikan layur (Trichiurus lepturus) merupakan komoditas utama yang bernilai ekonomis tinggi di Pangandaran. Penelitian ini bertujuan menentukan perbandingan selektivitas alat tangkap gillnet dengan hasil tangkapan ikan layur berdasarkan frekuensi panjang, proporsi hasil tangkapan utama dan sampingan, serta kurva selektivitas di Kabupaten Pangandaran. Data yang digunakan dalam penelitian ini adalah data primer dan sekunder. Data primer merupakan data hasil tangkapan dan panjang ukuran ikan. Data sekunder yang dikumpulkan adalah data produksi perikanan tangkap di Kabupaten Pangandaran. Analisis data dilakukan dengan bantuan software Microsoft Excel. Ikan layur di Kabupaten Pangandaran ditangkap menggunakan alat tangkap gillnet dan pukat pantai, walaupun didominasi oleh gillnet. Hasil penelitian menunjukkan gillnet berukuran mata jaring 3 inci dengan nilai L75 = 73,2 cm dan S31 = 0,64 lebih selektif dibanding gillnet ukuran mata jaring 2 inci dengan nilai L75 $=69,2 \mathrm{~cm}$ dan S2l = 0,62. Alat tangkap gillnet ukuran mata jaring 3 inci lebih selektif menangkap ikan layur yang sudah layak tangkap di Kabupaten Pangandaran dibandingkan dengan gillnet ukuran mata jaring 2 inci.
\end{abstract}

Kata kunci: gillnet, selektivitas, Trichiurus lepturus, Pangandaran

\begin{abstract}
Largehead hairtail (Trichiurus lepturus) is main commodity with high economic value in Pangandaran. This study aims to determine the comparison of gillnet selectivity with Trichiurus lepturus catches based on long frequencies, the proportion of main and side catches, and selectivity curves in Pangandaran Regency. Data collected are primary and secondary data. Primary data is the catch data and fish length length. Secondary data collected is data on capture fisheries production in Pangandaran Regency. Data analysis was performed with the help of Microsoft Excel software. Largehead hairtail are caught using gillnets. The results showed that gill nets with 3-inch mesh sizes with a value of $L 75=73.2 \mathrm{~cm}$ and S3I $=0.64$ were more selective than gill nets with a size of 2 inches with L75 $=69.2 \mathrm{~cm}$ and S2I =0.62. Gillnets 3 inch are more selective in catching largehead hairtail fish that are already feasible to catch in Pangandaran District compared to gills nets 2 inch size.
\end{abstract}

Key words: gillnets, selectivity, Trichiurus lepturus, Pangandaran 


\section{PENDAHULUAN}

Kabupaten Pangandaran adalah wilayah yang bertumpu pada beberapa sumber sektor perekonomian, diantaranya sektor pariwisata bahari dan juga sub sektor perikanan tangkap. Sektor ini tercatat memberikan kontribusi besar sejak 1999-2009 bagi perekonomian daerah dan masyarakat sekitar dengan pencapaian maksimum sebesar Rp22.096.074.398,00 (Nurhayati 2013). Salah satu potensi sumberdaya ikan adalah ikan layur. Ikan layur adalah salah satu jenis ikan ekonomis tinggi (Panggabean 2015). Pengoperasian alat tangkap dalam memanfaatkan ikan-ikan yang berada di perairan Pangandaran khususnya ikan layur cukup beragam, terdiri dari pukat pantai, pancing rawai, jaring dogol, gillnet dan trammel net (Fauzy 2009). Penelitian Rosyid et. al. (2005) menyatakan bahwa perbedaan waktu dalam operasi penangkapan dapat mempengaruhi pada hasil tangkapan. Waktu sebagai bagian dar upaya pemanfaatan ini diharapkan dapat ditingkatkan efektivitasnya sehingga dapat meningkatkan pendapatan, memenuhi konsumsi ikan bagi masyarakat lokal serta mendukung kegiatan ekspor komoditas ikan layur.

Sparre dan Venema (1998) berpendapat bahwa tingkat kemampuan alat tangkap untuk mencegah lolosnya ikan setelah ikan berhadapan dan kontak dengan alat tangkap merupakan pengertian dari selektivitas alat tangkap. Salah satu metode yang digunakan untuk menentukan selektivitas adalah pembandingan langsung satu persatu alat tangkap yang beragam pada area tertentu dengan hasil tangkapan repesentatif sebagai standar untuk membandingkan semua jenis alat tangkap (Manoppo 1999). Penelitian lain yang dilakukan oleh Fridman (1986) menyatakan bahwa selektivitas suatu alat tangkap tergantung pada parameter rancang bangun, seperti ukuran mata jaring (mesh size), elastisitas benang, jenis material dan ukuran benang, hanging ratio serta kecepatan penarikan alat tangkap.

Kegiatan perikanan tangkap dalam upaya pemanfaatan sumberdaya ikan tidak dapat berjalan tanpa adanya sarana utama penangkapan yaitu alat tangkap (fishing gear). Menurut Nahlohy (2013), Alat tangkap yang ramah lingkungan dapat dikategrikan berdasarkan Code of Conduct for Responsible Fisheries (CCRF). Dalam upaya mewujudkan perikanan tangkap yang berkelanjutan yang merujuk kepada kaidah pengelolaan sumberdaya perikanan yang bertanggung jawab, maka dalam praktik pemanfaatannya harus dapat dilakukan secara bertanggung jawab (Responsible fisheries) (FAO 1995). Menurut FAO (2015) kriteria alat tangkap yang baik yaitu memiliki selektivitas yang cukup tinggi, tidak menyebabkan kerusakan habitat sebagai tempat tinggal ikan serta sebagai habitat organisme lain, menghasilkan ikan berkualitas tinggi, tidak membahayakan nelayan, produk aman bagi konsumen, bycatch rendah, dampak terhadap biodiversitas rendah, tidak menangkap atau membahayakan ikan yang dilindungi, dan dapat diterima secara sosial. Alat tangkap yang banyak beroperasi di perairan Pangandaran yaitu alat tangkap gillnet monofilament, gillnet multifilament, trammel net, jaring jogol (dogol), dan pancing rawai (DKPKP Kab. Pangandaran 2017). Tujuan riset ini adalah menentukan alat tangkap paling selektif untuk komoditas ikan layur berdasarkan kurva selektivitas di Kabupaten Pangandaran.

\section{METODE PENELITIAN}

Riset mengenai selektivitas alat tangkap gillnet ini dilaksanakan di Kecamatan Pangandaran, Kecamatan Parigi dan Kecamatan Cijulang Kabupaten Pangandaran Provinsi Jawa Barat pada Bulan Agustus 2018-Januari 2019. Riset ini dilakukan dengan menggunakan metode studi kasus dengan analisis deskriptif kuantitatif. Metode studi kasus yaitu riset ini memusatkan diri secara intensif terhadap satu obyek tertentu yaitu tingkat selektivitas alat tangkap di perairan dengan mempelajari sebagai suatu kasus (Boesono et. al. 2017). Analisis yang digunakan adalah deskriptif kuantatif, yaitu analisis untuk menggambarkan atau mendeskripsikan data yang diperoleh tidak bersifat generalis (Muhson 2006). Metode pengambilan sampel yang digunakan dalam riset ini adalah metode purposive sampling, Indikator yang digunakan dalam tahap pengamatan dalam penelitian ini adalah distribusi 
ukuran panjang hasil tangkapan ikan layur, proporsi hasil tangkapan utama dan sampingan dan kurva selektivitas dari alat tangkap gillnet yang digunakan untuk menangkap ikan layur.

Analisis data yang digunakan dalam penelitian ini yaitu menghitung distribusi ukuran panjang dari ikan layur hasil tangkapan untuk mengetahui kelayaktangkapan ikan layur hasil tangkapan pada masing-masing alat tangkap, analisis proporsi hasil tangkapan utama dan sampingan yaitu data jumlah dan ukuran HTU dan HTS dari operasi penangkapan yang dihitung dalam bentuk persentase dan dibandingkan antara HTU dan HTS yang lebih besar proporsinya, selanjutnya kurva selektivitas dibuat untuk menentukan peluang tertangkapnya ikan pada alat tangkap.

Pengukuran ukuran panjang ikan layur hasil tangkapan dilakukan untuk menentukan kelayakan biologi ikan layur hasil tangkapan. Pengukuran seluruh ikan layur sebagai hasil tangkapan utama maupun sampingan dilakukan setelah sampai di darat dengan menggunakan meteran dengan skala ketelitian $0,1 \mathrm{~cm}$. Data yang didapatkan dicatat dan dihitung rata-ratanya. Berdasarkan Fish Base (diakses 16 Januari 2019), panjang ikan layur layak tangkap adalah 63,9 cm. Ketentuan perhitungan proporsi hasil tangkapan ini yaitu jika HTU/HTS $\geq 60 \%$ banyak yang dimanfaatkan maka alat tangkap tersebut dapat dikatakan selektif (Suadela 2004) (Dewanti 2018).

Proporsi Hasil Tangkapan Utama (HTU) (\%)

$$
\frac{\text { Jumlah HTU }}{\text { Jumlah Hasil Tangkapan }} \times 100 \%
$$

Proporsi Hasil Tangkapan Sampingan (HTS) (\%)

$$
\frac{\text { Jumlah HTS }}{\text { Jumlah Hasil Tangkapan }} \times 100 \%
$$

Jumlah HTU pada rumus memiliki arti sebagai hasil tangkapan yang menjadi objek penelitian, yaitu ikan layur. Sedangkan jumlah HTS memiliki arti sebagai hasil tangkapan yang tidak dibuang dan bukan menjadi objek penelitian namun ikut tertangkap pada alat tangkap yang sama.

Selektivitas adalah sifat alat tangkap yang menangkap ikan dengan ukuran tertentu dan spesies dari sebaran populasi. Sifat ini terutama tergantung kepada prinsip yang dipakai dalam penangkapan dan bergantung juga pada parameter desain dari alat tangkap seperti ukuran mata jaring (Tambunan 2010). Iskandar (2009) dalam Hadi (2010) menyatakan bahwa peluang tertangkapnya ikan dapat digambarkan melalui salah satu dari empat model kurva selektivitas diantaranya; a) model log normal, b) model left skew, c) model normal, dan d) model logistic.

Berdasarkan penelitian yang dilakukan Manoppo (1999), perhitungan selektivitas dapat menggunakan interval titik tengah panjang seperti L25, L50, L75 yang memiliki arti peluang tertangkapnya ikan sebesar $25 \%, 50 \%$, dan $75 \%$ pada titik tengah panjang ikan yang didapatkan. Semakin besar persentase nilai L akan membuat alat tangkap tersebut semakin dapat dikatakan selektif. Data panjang ikan layur hasil tangkapan dianalisis dengan menggunakan formula selektivitas Sparre dan Venema dalam Walus (2001):

$$
S_{L}=\exp \left[-\frac{(L-L m)^{2}}{2 S^{2}}\right]
$$

Keterangan:

SL $\quad$ : Peluang tertangkapnya ikan dengan panjang L $(\mathrm{cm})$ dengan ukuran mata jaring tertentu.

$\mathrm{Lm} \quad$ : Panjang maksimum ikan yang tertangkap dengan ukuran mata jaring tertentu.

L $\quad$ : Panjang total ikan yang tertangkap oleh alat tangkap dengan mata jaring tertentu

S : Standar deviasi 
Panjang maksimum didapat dari persamaan:

$$
L m=S_{F} \times m
$$

Keterangan:

SF : konstanta faktor selektif

m : ukuran mata jaring

Nilai faktor seleksi, SF dapat dihitung bila nilai intercept, a dan slope b diketahui. Nilai a dan b bisa didapat dari perhitungan regresi linier yang dilakukan dengan mengregresikan total length antara ukuran mata jaring yang saling tumpang tindih dengan nilai logaritma perbandingan antara mata jaring. Nilai a dan b di atas kemudian disubstitusikan ke dalam persamaan Sparre dan Venema (1989) berikut:

$$
S_{f}=\frac{-2 a}{b(m a+m b)}
$$

Standar deviasi dapat dicari dengan rumus:

$$
S=\sqrt{\frac{-2 a(m b-m a)}{b^{2}(m a+m b)}}
$$

Keterangan:

$$
\begin{array}{ll}
\mathrm{a} & : \text { intercept } \\
\mathrm{b} & : \text { slope } \\
\mathrm{ma} & \text { : ukuran mata jaring ke-1 } \\
\mathrm{mb} & \text { : ukuran mata jaring ke-2 }
\end{array}
$$

Selain melihat persentase nilai L untuk menentukan selektif atau tidaknya suatu alat tangkap, selektivitas dapat ditentukan dengan melihat dari nilai probabilitas atau selektivitas (S) (dalam hal ini adalah peluang tertangkapnya ikan layur), pada mesh size tertentu. Probabilitas adalah nilai yang digunakan untuk mengukur peluang atau kemungkinan. Probabilitas umumnya dinyatakan dalam desimal (seperti 0,75) juga pecahan seperti 75/100. Nilai dari probabilitas berkisar antara 0-1. Jika nilai $\mathrm{S}$ semakin dekat ke angka 0 , maka alat tangkap semakin tidak selektif. Sebaliknya jika semakin dekat nilai ke nilai 1,00 maka alat tangkap dapat dikatakan selektif menangkap ikan target (Indah 2014).

\section{HASIL DAN PEMBAHASAN}

Alat tangkap yang digunakan di Kabupaten Pangandaran sangat beragam, akan tetapi tidak semua alat tangkap dapat digunakan untuk menangkap ikan layur setiap harinya. Biasanya nelayan Kabupaten Pangandaran menggunakan alat tangkap yang berbeda melihat dari musim. Berdasarkan hasil penelitian yang dilakukan, alat penangkap ikan layur di Kabupaten Pangandaran yang paling banyak digunakan ialah gillnet dan pukat pantai.

Gillnet adalah alat tangkap yang bersifat pasif. Berdasarkan hasil wawancara dengan nelayan dan observasi yang dilakukan, gillnet nelayan Pangandaran termasuk bottom gillnet, memiliki badan jaring dengan mesh size 2 dan 3 inci, panjang tali utama $250 \mathrm{~m}$, panjang badan jaring, tali ris atas, dan tali ris bawah $200 \mathrm{~m}$, pelampung yang diikat dengan tali utama terbuat dari styrofoam bekas, pemberat yang diikatkan pada tali ris bawah terbuat dari timah berbentuk bulat yang dioperasikan oleh 2 hingga 3 orang nelayan di dalam satu kapal setiap melakukan kegiatan penangkapan (Gambar 1). 

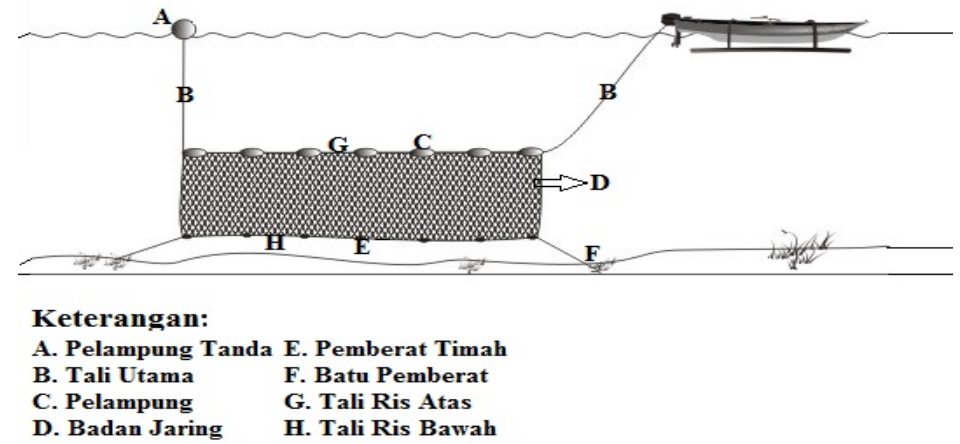

Gambar 1 Sketsa konstruksi alat tangkap gillnet

Hasil Tangkapan tangkapan gillnet di Kabupaten Pangandaran beragam. Jarak daerah penangkapan ikan dari Pesisir $>1$ mil laut $(1,852 \mathrm{~km})$ ke arah perairan Nusakambangan yang dioperasikan di perairan pada kedalaman 20-50 m. Perjalanan menuju fishing ground memakan waktu hampir 1-2 jam, waktu setting dan soaking 50 menit dengan kondisi mesin kapal dalam keadaan mati, waktu hauling 1,5-2 jam dengan menggunakan kapal <5 GT yang dibantu mesin motor tempel.

Berdasarkan observasi, ikan layur banyak ditangkap oleh nelayan dengan alat tangkap gillnet dan pukat pantai, tertangkapanya ikan layur oleh kedua alat tangkap ini memiliki pengaruh yang signifikan terhadap produktivitas alat tangkapnya (Tabel 1).

Tabel 1 Produktivitas alat tangkap ikan layur selama penelitian

\begin{tabular}{cccc}
\hline Alat Tangkap & Produksi Layur (Ton) & Effort (Trip) & Produktivitas (Ton/Trip) \\
\hline Gillnet & 0,237 & 18 & 0,013 \\
\hline
\end{tabular}

Tabel 2 Hasil tangkapan selama penelitian

\begin{tabular}{clcc}
\hline Alat Tangkap & \multicolumn{1}{c}{ Hasil Tangkapan } & Jumlah (Ekor) & Bobot (Kg) \\
\hline \multirow{6}{*}{ Gillnet } & Rajungan (Portunus pelagicus) & 33 & 6,9 \\
& Ikan Lidah (Cynoglossus lingua) & 35 & 7,5 \\
& Ikan Kuniran (Upeneus moluccensis) & 43 & 3,5 \\
& Ikan Gulamah (Johnius trachycephalus) & 75 & 6,2 \\
& Ikan Lainnya & 86 & 34 \\
& Ikan Boloho (Euthynnus affinis) & 96 & 10,1 \\
& Ikan Bawal Hitam (Parastromateus niger) & 155 & 25,2 \\
& Ikan Pepetek (Leiognathus equulus) & 236 & 15,6 \\
& Ikan Bawal Putih (Pampus argenteus) & 249 & 29,2 \\
& Ikan Ekor Kuning (Caesio cuning) & 263 & 16,7 \\
& Ikan Layur (Trichiurus lepturus) & 1398 & 82,4 \\
\hline
\end{tabular}

Berdasarkan Gambar 15 dan Tabel 8, hasil tangkapan selama penelitian pada alat tangkap gillnet mampu menangkap 2.669 ekor ikan dengan bobot total hasil tangkapan sebesar 237,3 kg. Hasil tangkapan terdiri dari jenis ikan pelagis dan demersal yang berbeda spesies. Total hasil tangkapan alat 
tangkap gillnet selama penelitian hampir semuanya didominasi oleh hasil tangkapan utama yaitu ikan layur. Sebanyak 1.398 dari 2.669 ekor ikan yang tertangkap, ikan layur merupakan hasil tangkapan utama terbanyak dengan persentase sebesar 52,38\%. Sedangkan proporsi jumlah hasil tangkapan sampingan pada alat tangkap gillnet selama penelitian berjumlah 1.271 ekor, terdiri dari rajungan, ikan lidah, kuniran, gulamah, boloho, bawal hitam, pepetek, bawal putih, ekor kuning, dan 18 spesies ikan lainnya dengan persentase sebesar 47,62\%. Berdasarkan proporsi hasil tangkapan yang didapatkan, tingkat selektivitas gillnet yang digunakan nelayan Kabupaten Pangandaran dapat dikategorikan ke dalam alat tangkap yang selektif menangkap ikan layur, dikarenakan hasil tangkapan ikan layur lebih banyak dibanding hasil tangkapan sampingan. Besarnya persentase ikan layur yang didapatkan sejalan dengan penelitian yang dilakukan Prasetyo et al. (2015) yang mendapatkan ikan layur hasil tangkapan di pantai selatan Kebumen adalah tangkapan terbanyak kedua setelah ikan bawal putih (28,16\%) yang memiliki persentase sebesar 19,42\% dari 5 spesies ikan yang tertangkap.

Kurva selektivitas adalah perhitungan lain untuk menentukan selektif atau tidaknya suatu alat tangkap dengan menghitung nilai probabilitas atau peluang tertangkapnya ikan layur pada masingmasing alat tangkap. Kurva selektivitas hanya dapat menggambarkan peluang tertangkapnya satu spesies ikan pada alat tangkap tertentu yang berisikan perpaduan antara koordinat sumbu X dan $\mathrm{Y}$, dimana sumbu $\mathrm{X}$ adalah ukuran ikan sedangkan sumbu $\mathrm{Y}$ adalah peluang ikan pada ukuran tertentu tertangkap pada alat tangkap tertentu. Penilaian tingkat selektivitas merujuk pada pernyataan Manoppo (1999) dan Indah (2014) yang menyatakan bahwa semakin besar persentase nilai L dan semakin dekat nilai S ke angka 1,00 akan membuat alat tangkap tersebut semakin dapat dikatakan selektif.

Holt (1963) dalam Sparre dan Venema (1998) menyarankan suatu percobaan untuk mengestimasi Lm dengan menggunakan dua alat tangkap dengan ukuran mata jaring berbeda, ma dan mb. Hal tersebut diperlukan untuk mengobservasi selektivitas jumlah yang tertangkap berdasarkan kelompok panjang ikan hasil tangkapan. Berdasarkan gambar kurva selektivitas hasil penelitian yang dilakukan (Gambar 2 dan 3), terdapat perbedaan antara kurva selektivitas mesh size 2 inci dengan kurva selektivitas mesh size 3 inci. Kurva selektivitas gillnet mesh size 2 inci termasuk ke dalam kurva left skew atau kurva yang menjulur ke kiri. Rata-rata nilai seleksi yang didapatkan pada kurva yaitu S2l = 0,62 dengan nilai L75 =69,2 cm. Berbeda dengan kurva selektivitas ukuran mata jaring 3 inci, kurva tersebut masuk kedalam kurva log normal atau kurva yang menjulur ke kanan yang memiliki rata-rata nilai seleksi S31 = 0,64 dengan nilai L75 $=73,2 \mathrm{~cm}$.

Gillnet dengan ukuran 3 inci lebih selektif dibandingkan gillnet dengan ukuran 2 inci. Hasil penelitian yang dilakukan berhasil membuktikan penelitian sebelumnya yang dilakukan oleh Syafriadi et. al. (2018) yang meneliti selektivitas gillnet dengan ukuran mata jaring 1,75 dan 1,5 inci, didapatkan gillnet ukuran mata jaring 1,75 inci dengan nilai ragam 5,66 lebih selektif menangkap ikan kapiek berukuran paling panjang $(16-24 \mathrm{~cm})$ sebanyak 11 ekor dibandingkan gill net ukuran mata jaring 1,5 inci yang memiliki nilai ragam 6,03 yang hanya menangkap 5 ekor ikan kapiek ukuran 16-21 cm saja. 


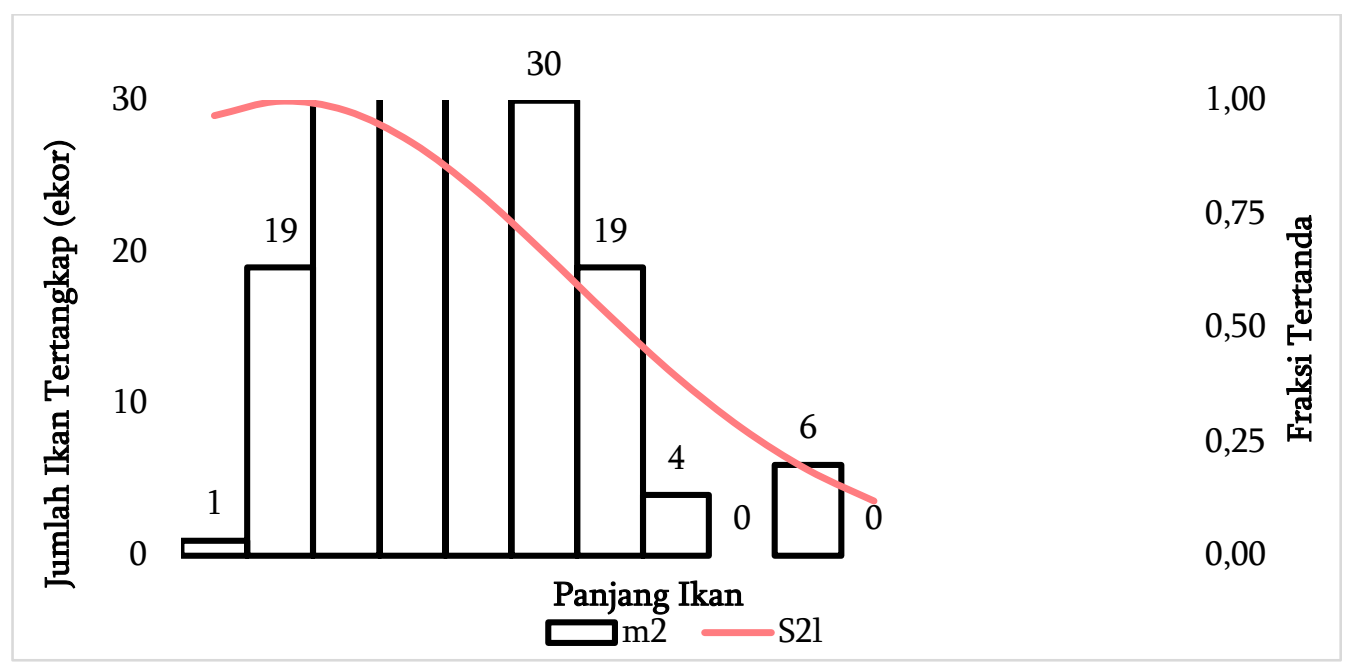

Gambar 2 Kurva selektivitas gillnet 2 inci

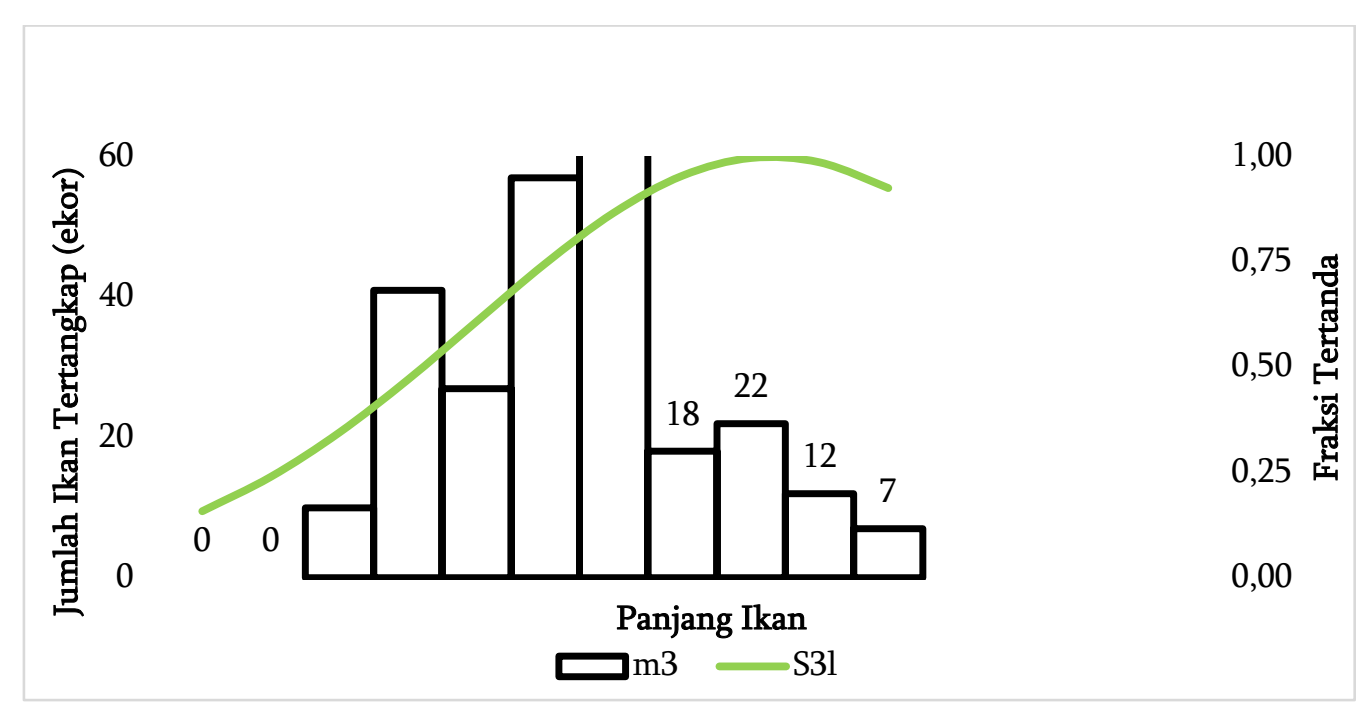

Gambar 3 Kurva selektivitas gillnet 3 inci

\section{KESIMPULAN DAN SARAN}

Berdasarkan hasil penelitian dapat disimpulkan bahwa kurva selektivitas menunjukkan gillnet mesh size 3 inci dengan nilai L75 = 73,2 cm dan S31 = 0,64 lebih selektif dibanding gillnet 2 inci dengan nilai L75 $=69,2 \mathrm{~cm}$ dan S21 =0,62. Alat tangkap gillnet mesh size 3 inci lebih selektif menangkap ikan layur di Kabupaten Pangandaran dibandingkan dengan gillnet mesh size 2 inci, pukat pantai mesh size 1,25 dan 2,25 inci.

\section{DAFTAR PUSTAKA}

Badan Pusat Statistik Jawa Barat. 2018. Laporan Tahunan Badan Pusat Statistik Jawa Barat. BPS: Jawa Barat.

Boesono H, Nugroho W, Setiyanto I. 2017. "Eco-Friendly Analysis of Mackarel Gillnet (Millenium Gillnet) Towards Fishing Catch in Pati Waters". FPIK. Universitas Diponegoro. Semarang

Dewanti PL, Apriliani IM, Faizal I, Herawati H, Zidni I. 2018. Perbandingan Hasil dan Laju Tangkapan Alat Penangkap Ikan di TPI Pangandaran. Jurnal Akuatika Indonesia. 3(1): 54-59. 
Dinas Kelautan dan Perikanan (DKP) Kabupaten Ciamis. 2007. Laporan Statistik Perikanan Tangkap dan Budidaya Tahun Anggaran 2006. Ciamis.

Dinas Ketahanan Pangan Kelautan Perikanan (DKPKP) Kabupaten Pangandaran. 2016. Statistik Perikanan Kabupaten Pangandaran Tahun 2016. Laporan Tahunan, Pangandaran: Dinas Ketahanan Pangan Kelautan Perikanan Kabupaten Pangandaran.

Dinas Perikanan dan Kelautan Pemerintah Provinsi Jawa Barat. 2013. Laporan Data Statistik Perikanan dan Kelautan Jawa Barat Tahun 2013. Bandung.

Direktorat Jenderal Perikanan. 1998. Buku Pedoman Pengenalan Sumber Perikanan Laut. Jakarta: DJP Departemen Pertanian.

Fauzy IR. 2009. Analisis Perikanan Tangkap Pasca Tsunami di Pangandaran Kabupaten Ciamis, Jawa Barat. [Skripsi]. Program Studi Pemanfaatan Sumberdaya Perikanan. FPIK. IPB. Bogor. 84 hal.

Fish Base. 2019. Length at First Maturity / Size / Weight / Age. Diakses 16 Januari 201919.25 WIB. http://www.FishBase.org/summary/Trichiurus-lepturus.html

Food Agriculture Organization (FAO). 1995. Code of Conduct for Responsible Fisheries. FAO Fisheries Departement.

Fridman A. 1986. Calculation for Fishing Gear Designs. FAO an Agricultur Organization of The United Nation. Rome. Pages 3-6.

Hadi WY. 2010. Selektivitas Celah Pelolosan terhadap Hasil Tangkapan Sampingan Dominan Bubu Tambun di Pulau Panggang, Kepulauan Seribu. [Skripsi]. Dept. Pemanfaatan Sumberdaya Perikanan. FPIK. IPB. Bogor.

Hasan MI. 2001. Pokok-pokok Materi Statistik I (Statistik Deskriptif). Bumi Aksara: Jakarta.

Indah NM. 2014. Statistika Deskriptif dan Induktif. Graha Ilmu: Yogyakarta

Manoppo L. 1999. Selektivitas Gill net Hanyut Terhadap Ikan Cakalang (Katsuwonus pelamis) di Perairan Lepas Pantai Selatan Jawa Barat. [Thesis]. Program Studi Teknologi Kelautan. FPIK. Institut Pertanian Bogor. Bogor.

Muhson A. 2006. Teknik Analisis Kuantitatif. Universitas Negeri Yogyakarta. Yogyakarta.

Nahlohy AC. 2013. Evaluasi Alat Tangkap Pelagis yang Ramah Lingkungan di Perairan Maluku dengan Menggunakan Prinsip CCRF (Code of Conduct for Responsible Fisheries. Jurnal Ilmu Hewani Tropika. 2(1): 1-11.

Nurhayati A. 2013. Analisis Potensi Lestari Perikanan Tangkap di Kawasan Pangandaran. Jurnal Akuatika. 4(2): 195-209.

Panggabean AS, Suman A, Sostenes A. 2015. Dinamika Populasi Sumber Daya Ikan Layur (Trichiurus lepturus, Linnaeus,1758) di Perairan Cilacap dan Sekitarnya. Jurnal Penelitian Perikanan Indonesia. 21(3).

Prasetyo W, Rosyid A, Ayunita D. 2015. Perbedaan Hasil Tangkapan dan Tingkat Keuntungan Nelayan Trammel Net dan Nelayan Gill Net di Perairan Pantai Pasir, Kecamatan Ayah, Kabupaten Kebumen. Journal of Fisheries Resources Utilization Management and Technology. 4(4): 116124.

Rosyid A, Jayanto BB, Amaludin A. 2005. Pengaruh Perbedaan Waktu Penangkapan dan Jenis Umpan Terhadap Hasil Tangkapan Kepiting Bakau dengan Alat Tangkap Wadong. Prosiding Seminar Perikanan Tangkap 15. Universitas Diponegoro. Semarang. Hal 1-7. 
Sparre P, dan Venema SC. 1998. Introduction to Tropical Fish Stock Assement. Part/Manual 1. FAO Fisheries Technical Paper. Roma.

Suadela P. 2004. Analisis Tingkat Keramahan Lingkungan Unit Penangkapan Jaring Rajungan Studi Kasus di Teluk Banten. [Skripsi]. FPIK. IPB. Bogor.

Syafriadi R, Nofrizal, Isnaniah. 2018. Selektivitas Alat Tangkap Gill net di Desa Pongkai Istiqomah Kecamatan XII Koto Kampar Kabupaten Kampar Provinsi Riau. JOMFAPERIKA.5

Tambunan SBS dan Agustriani F. 2010. Selektivitas Drift Gillnet pada Ikan Kembung Lelaki (Rastrelliger kanagurta) Di Perairan Belawan Pantai Timur Sumatera Utara Provinsi Sumatera Utara. Maspari Journal: Marine Science Research. 1(1):63-68.

Undang-undang Republik Indonesia Nomor 21. 2012. [Online]. Tersedia: https://www.hukumonline.com/pusatdata/detail/lt50d03918285dc/nprt/lt4f2a51338fbaf/uu-no21-tahun-2012-pembentukan-kabupaten-pangandaran-di-provinsi-jawa-barat yang direkam pada 17 November 2012. Diakses pada 3 Juni 201814.00 WIB.

Walus S. 2001. Studi Selektivitas Gill net Hanyut Terhadap Ikan Cakalang (Katsuwonus pelamis) di Perairan Pelabuhan Ratu. [Skripsi]. FPIK. IPB. Bogor. 58 hal. 